\title{
NOTAS
}

\section{Rey Páxaro (Un personaje folklórico desconocido y olvidado)}

(...) Solíase usar en toda España, y aora se haze en muchas partes: que el día de sancto Nacimiento de IESÚS, a vísperas señalauan un Rey Páxaro en remembrança de los tres Reyes Magos que vinieron a adorar al Niño IESÚS, nuestro Dios, Señor y Padre, quando nasció en Bethleem, para bien y redempción del género humano: y este Rey Páxaro acaba su reynado el día de los Sanctos Reyes, cuya fista celebramos a los treze ${ }^{1}$ días del Sancto Nascimiento, en estos treze días

1 E otrosy deues saber que este número treze e este santo dia [de Reyes] ha Dios consagrado segund que paresce por muchas vias. La primera porque en este trezeno día de su natividad el Salvador quiso ser baptizado quando ouo treynta años perfectos. E el año siguiente en aquel mesmo día fizo el primer miraglo convertiendo el aguau en vino. E después en aquel mesmo día predicando hartó cinco mill hombres de cinco panes, segund que paresce en el sesto capítulo de San Juan. E todo esto, dice Beda, era misterio ascondido sobre las grandes obras que el Salvador había de fazer en el mundo trayendo assí las ánimas de los escogidos. Mas en especial el avenimiento destos tres reyes al Salvador en treze días, dice Beda, que fue figura de la conversión de los gentiles, la cual se había de fazer al trezeno ternario de año en el cual Constantino Emperador de Roma fue convertido a la fe cathólica e el Imperio fue puesto so el yugo de la ley de Ihesu Christo con todas aquellas honrras y preminencias que había profetizado Ysaýas en el sesagésimo capítulo. E esto da a entender segund que él dize, este nombre [número] de treze el cual por el dezenario significa la ley de Dios, que está en diez mandamientos, e por el ternario es entendida la Santa Trinidad de la qual desciende la dicha ley e la plantó en el coraçón de los gentiles por predicación.

Eximenis-Talavera.-Vita Cristi.-Granada, 1496, cap. CLXXII, fol. 111.

Siguiendo este modo de pensar, Gil Vicente - pocos años después- en el Auto de los Reyes Magos lo recuerda así:

\footnotetext{
Dios plegue, ¿quién me dirá

a do está

este niño que es nacido?

Que ando bobo perdido,

sin sentido,

trece días per habrá

que no sé que haya ya..

Trece días son pasados, bien contados, que ando, perdido el tino, sin hallar nengún camino;

ni soy dino

de lo ver por mis pecados.
}

GIL VICENTE, Obras (Lisboa, 1852), t. I, pp. 22 y 24. 
se huelgan ${ }^{2}$ los pueblos, y los Alcaldes dexan las varas, cría el rey capitanes, mayordomos, alguaziles, carceleros, y escriuanos: y ay hombres graciosos ${ }^{3}$ que predican y dizen cosas con que el pueblo toma contento pues en estos treze días se puede mandar que este Rey Páxaro tenga facultad para hazer que la gente de cada pueblo salga a remediar, y a allanar los caminos, y en las partes que aya arroyadas ${ }^{4}$, allanen los barrancos, y planten en ellos muchos juncos y álamos, porque la junquera tiene y retiene la tierra y aguaduchos ${ }^{5}$, que no rompan ni corra la tierra, y demás desto, aquella tierra está perdida, y lleuando muchas junqueras, aurá para pasto a los bueyes, y yerua para las ouejas, porque por la mayor parte donde se hazen tales quebradas, es en las tierras hondas donde acuden los aguaduchos, y arroyos: y también pueden adouar ${ }^{6}$ algunos pantanales ${ }^{7}$ que ay en tierras floxas ${ }^{8}$, y aguanosas ${ }^{9}$, para que puedan nauegar, y andar las gentes por el Reyno, que es cosa lastimosa en tiempo de inuierno, ver como anda la gente perdida, y sin saber qué se haga: (...) el Rey Páxaro auía de tener potestad para condenar a los que no han adereçado sus pertenencias y caminos, hasta en cantidad de docientas doblas, que cada dobla se entienda un marauedí, y aun en una, o media arroba ${ }^{10}$ de vino, y destas penas han de comer y beuer aquellos días que fueren a aderezar los caminos, y aya su achaquero ${ }^{11}$ fiscal que denuncie los malos passos, por no auellos reparado el señor de la heredad, y desta manera haziendo en cada lugar ansí, estará todo el Reyno nauegable ${ }^{12}$, y en cada pueblo se holgarán y festejarán la fiesta del Sancto Nascimiento, y la venida de los tres Reyes Magos, y se holgarán y aprouechará a todos, y esto se haze en tiempo que no hará mal a ninguno, porque entonces no ay que hazer, y se hará harto en gastar aquel tiempo en seruicio de toda la república, y pueden hazer esto con su capitán, y zuyza ${ }^{13}$, y cabos de esquadra, y lleuar su atambor holgándose y obedeciendo todos al Rey y como si lo fuera (...).

- Se huelgan: descansan.

" Hombres graciosos: parece referirse a El Obispillo, El rey de la faba, El rey de los pastores o el Alcalde de los mozos.

- Arroyadas: sin duda regatos o torrenteras.

"Aguaduchos: charcos o zonas lagunosas. "Así como aguaducho que va por el valladow. Canciller Ayala, Rimado, est. 974́b.

- Adobar: reparar.

- Pantanales: almarjal o terreno pantanoso.

* Tierras floxas: improductivas, de poco valor.

$\checkmark$ Aguanosas: encharcadas.

10 Arroba: medida para líquidos equivalente a ocho azumbres — cada uno equivale a dos litros-, por tanto es un cántaro castellano o dieciséis litros.

11 Achaquero: juez o recaudador del Concejo de la Mesta.

12 Navegable: transitable, mejor que vadeable.

1.3 Zuiza: alguacil armado de chuzo. 


\section{COMENTARIO}

En 1572 nació Diego Gutiérrez de Salinas, hijo de Diego Gutiérrez y Jerónima de Salinas, fue bautizado en la iglesia de san Miguel de Brihuega (Guadalajara). Nada sabemos de sus estudios y vida, pero debió casarse muy joven pues antes de los veinte años había tenido tres hijos: Diego, Jerónimo, nacido en 1590 y Cristóbal en 1592.

En 1600, en Alcalá, publicó los Discursos sobre el pan y el vino del Niño Jesüs, que tuvo un estupendo éxito. Durante el medio siglo siguente se editaron cuatro Sumarios, de él, incluidos en sendas ediciones de la Obra de Agricultura de Gabriel Alonso de Herrera en 1605, 1620, 1643 y 1645. Aunque publicó una obrita poética, 23 octavas reales, en Loor de San José, fue póstuma, en 1629, pues había muerto en Alcalá el 18 de julio de 1610.

Aquel curioso libro se nos muestra extrañísimo, porque si por un lado parece referirse a la Eucaristía (pan y vino del Niño Jesús), por otro, es publicado a continuación de la Obra de Alonso de Herrera, un estudio sobre las labores campesinas. Como si fuera un Ingeniero Agrónomo especializado y revolucionario, ha recorrido aldeas y villorrios aconsejando a los campesinos cómo deben cultivar y cuáles son los mejores sistemas de trabajo. No es solamente un teórico sino un experimentador que imbuido, religiosa y socialmente, de unos conocimientos empíricos y prácticos se preocupa del pueblo y llama la atención real y de la Universidad de Alcalá donde, el $1 .^{\circ}$ de Noviembre de 1606 -cuando su obra hace cuatro años que se ha publicado- verifica que sus teorías - apoyadas en la filosofía natural - son viables, aprobadas y dignas de ser conocidas, por lo cual se acuerda adquirir un ejemplar para la Biblioteca del Colegio Mayor de San Ildefonso, y que se coloque en ella como los demás libros, esto es encadenado.

Los Discursos comienzan con los informes solicitados por el Rey Felipe II, a los labradores y alcaldes de Móstoles, Moraleja de Enmedio, Brihuega, Villafranca, Alcázar, Quero, El Casar, Ribatejada y Madrid; y se divide en tres libros:

I. [Trata] de las cosas que tocan al servicio de Dios y de las malas costumbres que tienen algunos labradores de maldecir, jurar y no decir la verdad; y del descuido de dezmar [pagar mal el diezmo] y cómo se ha de ordenar que diezmen bien, y desde la era. [No comienza halagando, antes, poniendo la verdad por delante, ataca los comportamientos sociales de raíz].

II. [Explica] cómo se han de arar las tierras para darles sazón y cómo las podrán volver en labor después de cohondidas [perdidas, convertidas en erial], y qué orden se ha de guardar en el ararlas y sembrarlas, para que el trigo nazca dentro de tres días a todo lo largo, y se pueda sembrar llegado Setiembre en todo tiempo que corriere, y sea la simencera tardía tan buena como la temprana, y se siembren dos diezmos menos, y se cojan tres diezmos más, en todos los años, respecto de lo que se había de coger según los temporales que corrieren. [Se incluyen las ocupaciones del viticultor, labores, abono, y poda, por cierto que se muestra partidario de que ésta sea tardía, cuando ya hay pámpanos y zarzillos, para evitar que los hielos tardíos dañen la vid]. Y el orden de sustentar los bueyes, y labrar con ellos, para que haya mucho pan y mucha carne, y de los daños que vienen de las mulas; se hace eco pues del refrán: Quien todo lo miró con bueyes aró.

III. Causas que ha habido para perderse los labradores y cómo podrán volver en sí... leyes que guardaban griegos y romanos... y cómo se conservarán en justicia, cómo se podrán abreviar los pleitos, y adobar los caminos, y plantar hi- 
gueras. [Dedica, pues, atención a la economía rural: observar los días de fiesta: que se reunan los labradores en estos días para intercambiar experiencias y mejorar sus conocimientos y práctica; crear una sociedad para ayudarse en casos de riesgos laborales, accidentes, destrucción de cosechas o vejez]. Un Reportorio, para que los labradores sepan las fiestas que hay cada mes, y los días que son forçosos de ayuno, y las cuatro témporas, cuántos son de luna.

En relación con los bienes de propiedad comunal, colectiva, copropiedad, común -aunque yo prefiero cualquiera de las dos denominaciones, primera y última - se incluye una figura el Rey páxaro que tiene todos los matices propios de un personaje folclórico, desconocido, y ya desgraciadamente desaparecido, pero...

¿Quién es el Rey páxaro? ¿Cuáles son sus orígenes? Sabemos, por Gutiérrez Salinas, su función; pero nuestro desconocimiento de la organización del trabajo comunal lo que compartimos con los historiadores dedicados a la vida campesina como N. Salomón, los folcloristas del mundo agrícola como Casas Gaspar, o aún los más conspicuos etnógrafos al estudiar las fiestas y personajes invernales como Caro Baroja.

El hecho es lamentable, pero ciertísimo, los Discursos es un libro ignorado por los historiadores del campo. Indudablemente por su aspecto ideológico externo no debió ser una obra atractiva de leer. Sin echarle un vistazo debió ser catalogado mentalmente, como tratadillo místico, añadido a una Obra de Agricultura de un sacerdote $-G$. Alonso de Herrera-, debieron pensar que, sin duda, era obra de otro sacerdote y que era un panfleto tridentino y en consecuencia no merecía la pena ni repasar las hojas. Pero hete aquí que, donde menos se espera salta la liebre - iy qué libre! - . Una figura sociológica campesina de primera magnitud y un aspecto folclórico ignorado y, sin embargo, necesitado de exposición, aclaración y estudio.

Siguiendo al concienzudo y bienintencionado Caro Baroja en relación con las fiestas invernales desde el día de Santa Lucía (13 de diciembre) a la Epifanía o Reyes Magos ( 6 de enero), pero más circunscritos, sin duda, al entorno de los Inocentes en general, se nos presentan una serie de personajes de carácter burlesco - San Nicolás, El Obispillo (Bisbetó en catalán), El rey de la Faba- y otros personajillos que tienen una función religioso-social: recaudar limosnas en pro de las ánimas benditas del Purgatorio: los "Inocentes" murcianos o almerienses, aragoneses; de Castellón, Cataluna o Romanillos (de Medinaceli), que aunque pueden tener ribetes humorísticos persisten con la misma ideología.

Hay otros como el alcalde de Mozas, el Mozo mayor y los Reyes de porqueros o de Pastores de recio abolengo y hasta convertidos en juegos de chiquillos: Lope de Vega lo trae a colación en Contra valor no bay desdicha (1625-30) en que Ciro, elegido rey por los hijos de los pastores, al castigar por desobediencia a uno, será reconocido por su abuelo que él ha hecho desterrar por temor al afatum»; o, como también hace Tirso de Molina - citado por Caro Baroja- en La elección por la virtud.

Estos Reyes de pastores pueden ser supervivencias o survival de tipos religiosos paganos que fueron adoptados por la nueva religión y desposeídos de ese valor litúrgico o, si se quiere, habiéndose realizado en ellos una inversión de funciones como, en relación con otros aspectos de la narrativa popular, propone Propp.

Es posible que los reyes saturnalicios o Nemorensis tuvieran, en principio, un mandato anual y después, fueran desterrados (como en el caso del cuento del 
Barlaam y Josaphat, J 711.3 - King for a year provides for future- y El Conde Lucanor núm. 49) e incluso que se preocuparan por el bien de la comunidad, y, como representante o descendiente de una familia sagrada (Saturno o cualquier otro, como el esposo de Diana- que dice Caro Baroja) tuviera la obligación o, al menos, la preocupación por el bienestar social de la comunidad y, aún quizá, atrajese la fecundidad campesina, que al fin y al cabo, como veremos, es una de las funciones, también, del Rey Páxaro.

De ser así, con el olvido total y absoluto, se ha consumado la evolución temporal: divinidad, familias descendientes, reyes campesinos (pastores, porqueros, pájaros), obligación de cuidar de la comunidad y atraer bienes de las divinidades (Dios o María), sustitución anual que observamos también en el cuento citado, elección democrática; y cuando el proceso de degradación e inversión se va agudizando: ordenación del trabajo comunal en brevísimo espacio temporal (13 días) para, realizando trabajos de adecentamiento de las comunicaciones y de los lugares insalubres, dar lugar a una mayor facilidad en el laboreo y fecundidad del territorio, produciendo un beneficio social.

Sin duda, con la expansión de la economía monetaria esto fue desapareciendo y comenzó a pagarse el arreglo de caminos, torrenteras y lugares pantanosos, con cargo a los bienes del Concejo o derramas. No obstante, todavía en mi infancia había unos días - generalmente festivos o de mal tiempo para labores- en que los aldeanos poniendo su propia persona, sus animales y aperos - carros-, amos, criados y jornaleros, contribuían al arreglo de baches, tollos, reparación de puentes y encauzamientos de lagunas o charcos perniciosos. Se hacía en esos días muertos para el trabajo campesino en que otros solían dedicarse al tejido de cestos de mimbre, preparación de mangos de azadas y legones, acarreo de leñas para camas y dentales del arado, reparar herramientas en la herrería o realizar pequeñas chapuzas domésticas.

Ahora creo que se puede entender el Rey Páxaro como una institución -quizá heredada - que, cuando la economía dineraria estaba en precario, servía para realizar los trabajos de la comunidad campesina que, sin duda contribuían al mejoramiento y calidad de las labores e incluso de la fecundidad del terreno. Si en este sentido heredó un cierto valor religioso sin duda, lo conservó en el sentido del refrán: A Dios rogando y con el mazo dando: ese mazo era el trabajo en beneficio de la sociedad que dirigía el Rey Páxaro, a quien todos obedecían, porque aumentaba la facilidad y fecundidad de los campos.

Como tantos otros aspectos tradicionales de la sabiduría popular, el tiempo, el dinero y la descreencia lo han corrompido; hoy no hay sacrificio personal más que el económico a través de los impuestos; aquella fraternidad o solidaridad del trabajo ha sido sustituida por un impuesto económico; antes todos contribuían por igual porque todos se beneficiaban por igual, hoy paga más quien más tiene, quizá sea más justo, pero menos igualitario en el trabajo, unos se eximen por no tener (bien) pero otros se discuplan de confraternizar por tener (mal).

\section{BIBLIOGRAFÍA}

Caro Baroja, J., El Carnaval, Madrid, Taurus, 1949, Parte III, Caps. I-VII, pp. 293-344. CASAS GASPAR, E., Folklore campesino español, Madrid, 1950. 
Gómez TABANERA, J. M. y Otros, El folklore español, Madrid, Instituto Español de Antropología, 1968, pp. 207-216.

Propp, V., Las raíces bistóricas del cuento, Madrid, Fundamentos, 1974, Cap. I, § 9 , pp. 26-30.

SAlOMÓN, Noel, La vida rural castellana en los tiempos de Felipe II, Barcelona, Ariel, 1982.

- Lo villano en el teatro del Siglo de Oro, Madrid, Castalia, 1985.

SIMON, J., Bibliografía de la Literatura Hispánica, Madrid, CSIC, 1976, t. XI, núm. 3547.

JOSÉ FRADEJAS LEBRERO

UNED. Madrid 